\title{
FAKTOR SOSIAL EKONOMI YANG BERHUBUNGAN DENGAN TINGKAT ADOPSI TEKNOLOGI USAHATANI PADI LAHAN PASANG SURUT
}

\author{
oleh \\ Basuki Sigit Priyono 1) \\ Bambang Sumantri 1) \\ Anna Suwarni 2) \\ 1) Staf Pengajar Jurusan Sosial Ekonomi Pertanian Fakultas Pertanian UNIB \\ 2) Mahasiswa Jurusan Sosial ekonomi Pertanian Fakultas Pertanian UNIB
}

\begin{abstract}
This Research was aimed to describ sources of family income from paddy farm, non paddy farm, livestock and estimated contribution of paddy revenue to total family income. This research conducted in the Srikaton village, Muara Padang - Musi Banyuasin District South Sumatera. The sudy revealed that involved frequency in extention activities and farm experience related to farmer adoption level. The revenue from paddy farm is Rp 7.347.142,86 and give contribution of $12,92 \%$ to total family income.
\end{abstract}

Key words : Social economic determinants, adoption, rice farming system, swamp land

\section{PENDAHULUAN}

Dari berbagai agroekosistem tersebut, lahan pasang surut merupakan alternatif pengembangan arealpangan. Lahan ini merupakan lahan yang memiliki karakteristik khusus diantaranya lahan ini tidak tergenang air pada pasang besar sekalipun, tetapi lahan menjadi jenuh air akibat dari rembesan air pada periode pasang besar.

Karakter lahan yang khas menyebabkan tingkat kesuburannya cenderung marginal, di mana produktifitas komoditi yang ditanam di atasnya kurang optimal. Namun demikian, kenyataan ini tidak menjadikan petani surut dalam mengelola lahan tersebut. Peningkatan mutu intensifikasi melalui pemanfaatan dari usahatani padi, usahatani non padi dan usaha non usahatani dalam satu tahun merupakan sumber penerimaan dari sebagian besar petani desa srikaton kabupaten musi banyuasin. penelitian ini bertujuan untuk mengetahui faktor sosial ekonomi yang berhubungan dengan tingkat adopsi teknologi usahatani padi lahan pasang surutserta menghitung sumbangan penerimaan dari usahatani padi terhadap total penerimaan keluarga petani dalam satu tahun

\section{METODE PENELITIAN}

Penentuan lokasi penelitian dilakukan secara sengaja (purposive) yaitu di Desa Srikaton Kecamatan Muara Padang Kabupaten Musi Banyuasin Propinsi Sumatera Selatan. Sampel pada penelitian ini adalah keluarga tani padi di lahan pertanian pasang surut dan sampel diambil secara acak. Data yang digunakan dalam penelitian ini adalah data primer dan sekunder. Untuk mengetahui hubungan antara variabel $X$ dan variabel $Y$ dilakukan dengan menggunakan analisis statistik non parametrik, yaitu uji koefisien korelasi rank spearman (Rs).Berdasarkan Siegel (1992), perhitungan koefisien korelasi rank spearman (Rs) secara matematis dirumuskan sebagai berikut : 


$$
r_{s}=1-\frac{6 \sum_{i=1}^{n} \mathrm{di}^{2}}{N\left(N^{2}-1\right)}
$$

Di mana:

Rs : Koefisien korelasi rank spearman

di : Selisih antara variabel $X$ dengan variabel $Y$ pada responden $k e-i$

i : Nomor responden

$\mathrm{N}$ : Jumlah responden

6 : Konstanta

Selanjutnya untuk mengetahui tingkat penerapan teknologi yang direkomendasikan, khususnya di lahan pasang surut yang meliputi pemilihan benih dan varietas padi, persemaian, pengolahan tanah, penanaman, drainase, pemupukan, penyulaman dan penyiangan, perlindungan tanaman dan pasca panen dilakukan dengan membuat daftar pertanyaan (kuisioner) yang berkaitan dengan topik dimaksud. Alternatif jawaban dalam kuisioner dinilai dengan tingkatan ya, selalu (5), kadang-kadang (3) dan tidak pernah (1). Tingkat adopsinya diukur dengan total skor dari sejumlah pertanyaan dalam kuisioner. Untuk pengkategorian variabel yang akan diteliti tersebut digunakan perhitungan standar deviasi dengan formulasi sebagai berikut (Subagyo, 1985) :

$$
S D=\sqrt{\frac{\sum_{I=1}^{N}\left(X_{I}-X\right)^{2}}{(N-1)}}
$$

Dimana :

$$
\begin{array}{ll}
X i & : \text { Jumlah Skor } \\
X & : \text { Rata-rata Skor } \\
N & : \text { Jumlah Sampel }
\end{array}
$$

Untuk mengetahui berapa besarnya sumbangan atau kontribusi usahatani padi terhadap total penerimaan keluarga petani dalam satu tahun dicari dengan pendekatan sebagai berikut (Suyono, 2000) :

$$
\mathrm{K}=\frac{\mathrm{R}_{1}}{\mathrm{R}_{\text {total }}} x 100 \%
$$

Di mana :

K : Besarnya sumbangan atau kontribusi usahatani padi terhadap total penerimaan keluarga petani dalam satu tahun

$\mathrm{R}_{1}$ : Penerimaan petani dari usahatani padi dalam satu tahun

$R_{\text {total }}$ : Total penerimaan petani dari seluruh usaha selama satu tahun 


\section{HASIL DAN PEMBAHASAN}

\subsection{Tingkat Adopsi Teknologi Pada Usahatani Lahan Pasang Surut}

Karakteristik petani di sini meliputi tingkat pendidikan (formal dan non formal), luas lahan yang dimiliki, pengalaman berusahatani dan mobilitas petani merupakan aspek-aspek yang baik secara langsung maupun tidak langsung menentukan tingkat adopsi teknologi usahatani padi terutama di lahan pasang surut. Disamping itu aspek mobilitas sosial petani yang menunjukkan frekuensi petani dalam melakukan perjalanan atau bepergian ke luar desa untuk mencari informasi pertanian relatif rendah, sehingga diperlukan upaya perbaikan dan peningkatan kemampuan petani dalam mengakses informasi dimaksud melalui penerapan teknologi baru.

Hasil penelitian menunjukkan bahwa penerapan dan penggunaan alat atau teknologi yang disampaikan oleh penyuluh, berupa pesan komunikasi, atau perasaan bahkan pesan informasi. Dalam penerimaan atau penerapan teknologi tentunya setiap petani atau individu berbeda-beda, dan hal ini akan mempengaruhi tingkat adopsi teknologi. Tinggi rendahnya produksi pertanian antara lain ditentukan oleh tingkat penerapan teknologi atau adopsi teknologi. Penggolongan tingkat adopsi teknologi yang dilakukan petani dapat dilihat pada Tabel 1 berikut.

Tabel 1. Tingkat Adopsi Teknologi Usahatani Padi Lahan Pasang Surut

\begin{tabular}{clc}
\hline No & Tingkat Adopsi & Persentase $(\%)$ \\
\hline 1 & Tinggi : $<303,09$ & 42,86 \\
2 & Sedang $: 250,63-303,09$ & 22,86 \\
3 & Rendah : $>250,63$ & 34,29 \\
\hline & Jumlah & 100,00 \\
\hline
\end{tabular}

Sumber : Data primer(2003)

Hasil penelitian yang terlihat pada Tabel 1 menunjukkan bahwa rata-rata skor jawaban petani terhadap skor teknologi yang dianjurkan adalah 276,86 dengan kisaran $174-352$. Petani yang tergolong memiliki tingkat adopsi tinggi sebanyak $42,86 \%$, tingkat adopsi sedang $22,86 \%$ dan tingkat adopsi rendah $34,29 \%$. Hal ini memperlihatkan bahwa petani memiliki tingkat adopsi tinggi terhadap teknologi untuk berusahatani.Kondisi tersebut memungkinkan petani akan berhasil dalam kegiatan usahataninya karena mereka menyadari betapa pentingnya teknologi pertanian yang tepat guna, apalagi untuk lahan yang memiliki spesifikasi tertentu seperti di daerah penelitian yaitu lahan pasang surut.

\subsection{Hubungan Faktor Sosial Ekonomi $(X)$ Dengan Tingkat Adopsi Teknologi $(Y)$ Usahatani Padi lahan Pasang Surut}

Untuk mengetahui hubungan antara variabel yang diduga mempengaruhi tingkat adopsi teknologi, seperti tingkat pendidikan formal, frekuensi mengikuti penyuluhan pertanian, pengalaman berusahatani, luas lahan garapan dan mobilitas sosial petani, digunakan uji korelasi Rank Spearman. Hasil uji statistik yang dilakukan dapat di lihat pada Tabel 2. 
Tabel 2. Hasil Analisis Rank Spearman Variabel $X$ dan Variabel $Y$

\begin{tabular}{lcc}
\hline \multicolumn{1}{c}{ Variabel } & $\mathbf{t}$ - hitung & Keterangan \\
\hline X1 (Tingkat Pendidikan Formal) dengan Y (Tingkat Adopsi Teknologi) & 0,14351 & $\mathrm{~ns}$ \\
X2 (Tingkat Pendidikan Formal) dengan Y & 3,00574 & $\star$ \\
X3 (Pengalaman Berusahatani) dengan Y & 2,12517 & $\star$ \\
X4 (Luas Lahan Garapan) dengan Y & $-0,80607$ & $\mathrm{~ns}$ \\
X5 (Mobilitas Sosial Petani) dengan Y & 0,52120 & $\mathrm{~ns}$ \\
\hline
\end{tabular}

Keterangan :

* = Berhubungan nyata pada taraf kepercayaan $95 \%(\alpha=0,05)$

ns $\quad=$ Tidak berhubungan nyata $t(\alpha / 2,29)=2,045$

\subsubsection{Hubungan Tingkat Pendidikan Formal dengan Tingkat Adopsi Teknologi}

Hasil analisis stastistik uji korelasi Rank Spearman menunjukkan bahwa variabel ini tidak berhubungan nyata pada taraf kepercayaan $95 \%(\alpha=0,05)$. Ini dapat dilihat dari koefisien korelasi thitung yang lebih kecil dari t-tabel $(0,14351<2,045)$, maka Ho diterima dan Ha ditolak, yang berarti tingkat pendidikan formal tidak berhubungan nyata dengan tingkat adopsi teknologi. Penyebabnya adalah bahwa untuk menerapkan suatu teknologi dalam usahataninya, petani tidak harus memiliki tingkat pendidikan formal yang tinggi. Petani memiliki keterampilan dan pengetahuan yang berbeda, dimana tidak semua petani berpendidikan tinggi memiliki keterampilan dan pengetahuan yang lebih tinggi dibandingkan petani yang tingkat pendidikannya rendah. Jadi, tingkat pendidikan formal yang dimiliki petani tidak dapat menjamin petani untuk berbuat atau berusaha sesuai dengan tingkat pendidikan formal yang dimilikinya sebab kegiatan usahatani yang dilakukan juga dipengaruhi oleh kemampuan petani sendiri dan situasi serta kondisi masyarakat petani disekitamya. Eratnya hubungan kekerabatan antar masyarakat yang mayoritas adalah etnis Jawa menyebabkan masyarakat akan saling memberitahukan jika ada pengetahuan atau sesuatu yang baru.

\subsection{2..Hubungan Frekuensi Mengikuti Penyuluhan Pertanian dengan Tingkat Adopsi Teknologi}

Hubungan nyata antara frekuensi mengikuti penyuluhan pertanian dengan tingkat adopsi teknologi pada taraf kepercayaan $95 \%(\alpha=0,05)$ karena t-hitung lebih besar dari t-tabel $(3,00574>2,045)$. Berarti frekuensi mengikuti penyuluhan pertanian berhubungan nyata dengan tingkat adopsi teknologi. Hubungan nyata antara frekuensi mengikuti penyuluhan pertanian sangat menentukan tingkat adopsi teknologi oleh petani. Informasi yang baru yang diperoleh dari penyuluh diharapkan memberikan informasi terbaru tentang teknologi baru berkaitan dengan usahatani di lahan pasang surut.

\subsubsection{Hubungan Pengalaman Berusahatani dengan Tingkat Adopsi Teknologi}

Variabel pengalaman berusahatani ini berhubungan nyata dengan tingkat adopsi teknologi pada taraf kepercayaan $95 \%(\alpha=0,05)$ dengan nilai nilai t-hitung lebih besar dari t-tabel $(2,12517>2,045)$. Artinya pengalaman berusahatani berhubungan nyata dengan tingkat adopsi teknologi. Hubungan nyata yang terjadi menunjukkan bahwa pengalaman berusahatani sangat menentukan tingkat adopsi teknologi, dimana semakin lama berusahatani maka pengalaman yang didapat semakin banyak Hasil 
sajalan dengan pendapat Soekartawi (1993) yang menyatakan bahwa semakin lama berusahatani, petani cenderung mempunyai sikap yang lebih berani dalam menanggung resiko penerapan teknologi baru. Dengan modal pengalaman dan dukungan sarana informasi yang tersedia, diharapkan petani akan mendapat informasi lain tentang pertanian selain dari sumber informasi utama yaitu penyuluh, untuk selanjutnya menilai dan menerapkan dalam usahataninya.

\subsubsection{Hubungan Luas Lahan Garapan dengan Tingkat Adopsi Teknologi}

Uji statistik menunjukkan bahwa luas lahan garapan tidak berhubungan nyata dengan tingkat adopsi teknologi pada taraf kepercayaan $95 \%(\alpha=0,05)$ dengan nilai t-hitung yang lebih kecil dari t-tabel ($0,80607>-2,045)$, sehingga luas lahan garapan tidak ikut menentukan tingkat adopsi teknologi. Penerapan teknologi pada lahan pasang surut membutuhkan biaya besar dengan semakin luasnya lahan yang digarap. Disamping itu kondisi lahan dengan segala konsekuensinya kadang-kadang menyebabkan produksi rendah sehingga penerimaan petani juga kurang maksimal. Masalah biaya inilah yang kemungkinan menyebabkan petani tidak mengadopsi teknologi secara maksimal. Disisi lain tidak adanya hubungan yang nyata ini menunjukkan luas sempitnya lahan garapan tidak mempengaruhi petani untuk mengadopsi suatu teknologi yang diperkenalkan. Pelaunag terbesar bagi petani untukmenerapkan teknologi baru jika teknologi dimaksud dapat menjamin keberhasilan usahataninya dengan luas lahan yang ada.

\subsubsection{Hubungan Mobilitas Sosial Petani dengan Tingkat Adopsi Teknologi}

Mobilitas sosial petani berdasarkan hasil uji statistik tidak hubungan nyata antara tingkat adopsi teknologi pada taraf kepercayaan $95 \%(\alpha=0,05)$ dengan nilai t-hitung lebih kecil dari t-tabel $(0,52120$ $<2,045$ ). Hubungan tidak nyata menunjukkan mobilitas petani tidak menjamin petani untuk tidak menggunakan teknologi berusahatani. Akan sangat wajar jika petani yang selalu bepergian akan cepat mengadopsi teknologi baru karena mereka mendapat informasi dari perjalanannya itu. Sebaliknya petani dengan tingkat mobilitas rendah juga menginginkan keberhasilan usahataninya dengan berusaha memperoleh informasi teknologi sesuai kemampuan. Informasi dimaksud dapat diperoleh melalui PPL atau masyarakat sekitar, aktif dalam forum kelompok tani, media elektronik seperti televisi dan dan radio

\subsection{Penerimaan Keluarga Petani Padi Lahan Pasang Surut}

\subsubsection{Penerimaan Usahatani Padi dan Non Padi}

Berdasarkan hasil penelitian diketahui bahwa penerimaan keluarga petani di lokasi penelitian sangat dipengaruhi oleh karakteristik pertanian di lahan pasang surut yang hanya menanam padi sekali dalam setahun menyebabkan petani dan keluarganya mencari sumber penerimaan lain, baik di sektor pertanian maupun non pertanian. Rata-rata penerimaan keluarga petani yang dihitung bersumber dari dari usahatani padi, non padi dan ternak.

Rata-rata luas lahan usahatani padi 2,23 Ha dengan tingkat produksi Gabah Kering Panen (GKP) selama musim tanam November - Maret 2001 sebesar 7.771,43 Kg/UT atau 3,4 ton/ $\mathrm{Ha}$. Produktivitas lahan lebih rendah jika dibandingkan dengan yang ditetapkan pemerintah yaitu $4-5$ ton/ Ha. Rendahnya produksi adalah karena pada musim tanam 2001 terjadi serangan hama wereng yang menyebabkan sebagian petani mendapatkan produksi yang kurang maksimal. 
Sebanyak $31,43 \%$ petani menanam tanaman non padi dengan rata-rata luas lahan yang diusahakan adalah $0,169 \mathrm{Ha}$. Jenis tanaman non padi yang ditanam petani adalah seperti cabe, kacang panjang dan ubi jalar. Rata-rata penerimaan dari usahatani non padi adalah Rp 187.181,82/UT. Jenis temak yang dipelihara oleh petani adalah ayam ayam dan sapi. Petani yang menjual temaknya untuk menutupi kebutuhannya sebanyak $34,29 \%$. Rata-rata penerimaan dari usaha temak adalah Rp 1.060.625,00/UT.

\subsubsection{Penerimaan Non Usahatani}

Sumber penerimaan petani di luar sektor pertanian meliputi buruh tanu, usaha jasa, home industri, berdagang dan Pegawai Negeri Sipil. Besamya rata-rata penerimaan dari kegiatan usaha jasa seperti menjadi penjahit, tukang ojek, P3N, buruh pabrik, buruh industri dan perangkat desa. Rp 3.627.272,73/Th. Rata-rata penerimaan dari Home Industri seperti tukang kayu, tukang besi, percetakan dan penggilingan padi adalah $\mathrm{Rp} 9.900 .000,00 \mathrm{Th}$. Rata-rata penerimaan keluarga yang memiliki warung dan toko baik di di rumah dan di pasar keliling (kalangan) adalah Rp 9.500.000/ Th. Sedangkan rata-rata penerimaan dari Pegawai Negeri Sipil (PNS) Rp 23.100.000,00/Th. Dari keseluruhan sumber penerimaan keluarga tersebut dapat diketahui jumlah total penerimaan rata-rata keluarga petani dalam satu tahun yaitu Rp $56.862 .936,70$. Secara terperinci, besamya rata-rata penerimaan keluarga petani dari masing-masing sumber dapat dilihat pada Tabel 3.

Tabel 3. Rata-rata Penerimaan Keluarga Petani PerTahun

\begin{tabular}{|c|c|c|}
\hline No & Sumber & Jumlah (Rp/Th) \\
\hline 1 & Usahatani Padi & $7.347 .142,86$ \\
\hline 2 & Usahatani Non padi & $187.181,82$ \\
\hline 3 & Usaha Temak & $1.060 .625,00$ \\
\hline 4 & Buruh Tani & $2.140 .714,29$ \\
\hline 5 & Usaha Jasa & $3.627 .272,73$ \\
\hline 6 & Home industri & $9.900 .000,00$ \\
\hline 7 & Dagang & $9.500 .000,00$ \\
\hline \multirow[t]{2}{*}{8} & PNS & $23.100 .000,00$ \\
\hline & Jumlah & $56.862 .936,70$ \\
\hline
\end{tabular}

Dari Tabel 3 tersebut terlihat bahwa dalam waktu satu tahun, penerimaan petani berasal dari sumber yang tetap dan tidak tetap. Penerimaan dari PNS merupakan penerimaan tetap setiap bulan, sedangkan penerimaan dari sumber yang lain tidak tetap. Walaupun penerimaan tersebut tidak tetap, namun memberikan penerimaan cukup besar. Secara keseluruhan, usahatani padi sebagai usaha pokok yang dilakukan oleh mayoritas petani memberikan hasil yang paling besar dibanding usaha lain. Namun begitu usahatani padi ini merupakan usaha yang memiliki ketidakpastian tinggi

\subsection{Sumbangan Penerimaan Usahatani Padi Terhadap Total Penerimaan Keluarga Petani}

Hasil penelitian menunjukkan bahwa rata-rata penerimaan keluarga petani dari usahatani padi adalah Rp 7.347.142,86 /tahun. Jumlah ini jika jika dibandingkan dengan total rata-rata penerimaan keluarga petani per tahun yaitu $\operatorname{Rp~} 56.862 .936,70$ akan menghasilkan nilai kontribusi rata-rata sebesar 12,92 $\%$, merupakan suatu nilai kontribusi yang tergolong sangat rendah. Besamya kontribusi setiap sumber penerimaan petani dapat dilihat pada Tabel 4 berikut. Dimana sumbangan usahatani padi 
dapat diartikan sebagai kontribusi yang dapat diberikan dari usahatani padi terhadap total penerimaan keluarga petani. Perhitungan kontribusi ini dilakukan dengan membandingkan penerimaan dari usahatani padi terhadap total penerimaan keluarga petani dalam satu tahun dikali seratus persen.

Tabel 4. Rata-rata Sumbangan Masing-masing Sumber Penerimaan Terhadap Total Rata-rata Penerimaan Keluarga Petani Dalam Satu Tahun

\begin{tabular}{clr}
\hline No & \multicolumn{1}{c}{ Sumber } & Sumbangan (\%) \\
\hline 1 & Usahatani Padi & 12,92 \\
2 & Usahatani Non padi & 0,33 \\
3 & Usaha Ternak & 1,87 \\
4 & Buruh Tani & 3,76 \\
5 & Usaha Jasa & 6,38 \\
6 & Home industri & 17,41 \\
7 & Dagang & 16,71 \\
8 & PNS & 40,62 \\
\hline
\end{tabular}

Berdasarkan kriteria yang dikemukakan oleh Diana (1998), maka kategori kontribusi penerimaan usahatani padi di lokasi penelitian terbagi atas sangat rendah (1 - 19\%), Rendah $(20-39 \%)$, Sedang ( $40-59 \%)$, Tinggi $(60-79 \%)$ dan Sangat Tinggi (> $80 \%)$. Tabel 4 menjelaskan bahwa nilai kontribusi penerimaan dari usahatani padi sebesar $12,92 \%$ tersebut walaupun sangat rendah namun secara ekonomi memberikan sumbangan yang cukup berarti bagi perekonomian keluarga petani. Untuk mencukupi kebutuhan keluarga, petani juga memanfaatkan lahan dan tenaga yang ada dengan menaman tanaman non padi, memelihara temak, menjadi buruh tani, menjual jasa, membuka home industri dan berdagang.

Masing-masing usaha memberikan kontribusi sebesar 0,33 \%; $1,87 \% ; 3,76 \% ; 6,38 \% ; 17,41 \%$ dan $16,71 \%$. Nilai kontribusi dari luar usahatani padi beragam mampu menjadi penyangga di saat usahatani padi mengalami kegagalan. Hasil penelitian Sutiyono (1985) dalam Prayitno dan Lincolin (1987) menunjukkan bahwa kontribusi pendapatan di luar usaha pokok terhadap pendapatan rumah tangga petani sebesar $16,22 \%$ memberikan indikasi bahwa peranan usaha sampingan mempunyai andil yang cukup dalam menyumbang pendapatan rumah tangga tani serta dalam upaya memenuhi kebutuhan rumah tangga.

\subsection{Kesimpulan}

\section{IV.KESIMPULAN DAN SARAN}

Berdasarkan hasil penelitian dan pembahasan yang telah dilakukan dapat ditarik kesimpulan sebagai berikut :

1. Faktor sosial ekonomi yang berhubungan nyata dengan tingkat adopsi teknologi usahatani padi lahan pasang surut di Desa Srikaton adalah frekuensi mengikuti penyuluhan pertanian dan pengalaman berusahatani, sedangkan tingkat pendidikan formal, luas lahan garapan dan mobilitas sosial petani tidak berhubungan nyata dengan tingkat adopsi teknologi.

2. Rata-rata penerimaan total keluarga petani adalah $R p 56.862 .936,70 \pi$ h yang berasal dari berbagai sumber yaitu dari usahatani padi, usahatani non padi dan usaha non usahatani dengan 
penerimaan rata-rata masing-masing sumber adalah $\mathrm{Rp} 7.347 .142,86 / \mathrm{Th} ; \mathrm{Rp} 1.247 .806,82 / \mathrm{Th}$ dan $\mathrm{Rp} 48.267 .987,02 \pi \mathrm{h}$. Dimana usahatani padi lahan pasang surut di Desa Srikaton hanya memberikan sumbangan sebesar $12,92 \%$ terhadap total penerimaan keluarga petani dalam satu tahun.

\section{2..Saran}

1. Sebaiknya pihak terkait memperbanyak kegiatan pendidikan non formal seperti meningkatkan intensitas penyuluhan pertanian untuk memaksimalkan tingkat adopsi teknologi. Petani sebaiknya lebih banyak memanfaatkan media komunikasi yaitu radio dengan banyak mendengar topik yang berkaitan dengan teknologi pertanian.

2. Petani sebaiknya memperhatikan pentingnya kegiatan penyulaman dan penyiangan serta pemupukan, sebab walaupun sebagian besar penerapan atau adopsi teknologi pertanian sudah dilakukan, namun kegiatan penyulaman dan penyiangaan serta pemupukan belum maksimal.

3. Untuk meningkatkan penerimaan keluarga petani, maka selain melakukan usaha pokok yaitu usahatani padi, petani juga dapat memanfaatkan lahan yang ada dengan menanam tanaman non padi setelah panen padi sampai musim tanam padi berikutnya.

\section{DAFTAR PUSTAKA}

Arifin, B, Chrisman. S, M.H Sawit, Muhajir. U. 1997. Pemberdayaan Lahan Kering Untuk Penyediaan Pangan Abad 21. Prosiding Seminar Nasional. PERHEPI. Jakarta.

Nazir, M. 1988. Metode Penelitian. Ghalia Indonesia. Jakarta.

Prayitno, $\mathrm{H}$ dan Lincolin, A. 1987. Petani Desa dan Kemiskinan. BPFE. Yogyakarta.

Rogers, E.M dan F.F. Shoemaker. 1987. Memasyarakatkan Ide-ide Baru. Terjemahan oleh Abdilah hanafi. Usaha Nasional. Surabaya.

Siegel, S. 1992. Statistik Non Parametrik. Gramedia Pustaka Utama. Jakarta.

Soekartawi. 1995. IImu Usahatani. CV Rajawali. Jakarta.

Subagyo, P. 1985. Statistik Deskriptif. BPFE. Yogyakarta.

Suhardiyono, 1992. Penyuluhan : Petunjuk Bagi Penyuluh Pertanian. Erlangga. Jakarta

Suyono. 2000. Analisa Kontribusi Pendapatan Usahatani dan Industri Penyulingan Nilam Terhadap Pendapatan Keluarga Petani. Skripsi Jurusan Sosial Ekonomi Pertanian. UNIB. Tidak dipublikasikan.

Syahrin. 1998. Bahan Materi Pelatihan Teknologi SutpaRawa Pasang Suru Bagi Petani. PPWT Inpres Dati II Kabupaten Musi Banyuasin. 